\title{
Coronavirus Disease 2019 in Kidney Transplant Recipients: Our Single Center Experiences
}

\section{Böbrek Nakli Alıcılarında Koronavirüs 2019 Hastalığı: Tek Merkez Deneyimlerimiz}

\section{Serdar Karadag ${ }^{1}$ (D), Ramazan $\operatorname{Ugur}^{1}$ (D), Emre Sam ${ }^{1}$ (D), Mithat Eksi ${ }^{1}$ (D), Yunus Colakoglu ${ }^{1}$ (D), Kadriye Kart $\operatorname{Kasar}^{2}$ (D)}

' Department of Urology, University of Health Sciences, Dr. Sadi Konuk Training and Research Hospital, Istanbul, Turkey

${ }^{2}$ Department of Infectious Diseases and Clinical Microbiology, University of Health Sciences, Dr. Sadi Konuk Training and Research Hospital, Istanbul, Turkey

Cite as: Karadag S, Ugur R, Sam E, Eksi M, Colakoglu Y, Kart Yasar K.

Coronavirus disease 2019 in kidney transplant recipients: our single center experiences. Grand J Urol 2021;1(3):109-115.

Submission date: 18 July 2021

Acceptance date: 28 August 2021

Online first: 03 September 2021

Publication date: 20 September 2021

Corresponding Author: Ramazan Ugur / University of Health Sciences, Dr. Sadi Konuk Training and Research Hospital, Department of Urology, Istanbul, Turkey / rugur23@gmail.com ORCID ID: 0000-0002-0593-8589

\section{Abstract}

Objective: To investigate whether tacrolimus (Tac), mycophenolate mofetil (MMF), mycophenolic acid (MPA), prednisolone (Pred) and methylprednisolone (MP) are affect the COVID-19 pathogenesis and on its progression in kidney transplantation recipients diagnosed with COVID-19 patients.

Materials and Methods: Among patients hospitalized due to COVID-19, patients who had kidney transplantation were retrospectively detected on the online database of our center. Referral complaints, laboratory and radiological data at referral, applied treatment protocols, and ultimate conditions of the patients were documented.

Results: Among the total of 11 patients, $73 \%$ (8) were male and 27\% (3) were female. The mean age was 49.63 (27-71). Hypertension and diabetes mellitus were the most common comorbid diseases. The most common symptoms were coughing, fever and exhaustion-fatigue. High serum reactive protein and lymphopenia were detected in almost all patients. Acute renal failure was observed in seven patients (73\%). While all patients were using Tac and Pred, nine patients (82\%) were using MMF and two patients (18\%) were using MPA. Hydroxychloroquine, favipiravir, and azithromycin were treatments for COVID-19. RT-PCR results of 11 patients were positive in 7 and negative in 4 patients. The mean hospital stay of the discharged patients was 8.8 days. Eight patients recovered and were discharged, treatment of two intubated patients continues in intensive care unit and one patient died. Conclusion: Clinical characteristics of COVID-19 in kidney transplanted patients are similar to the general population and it should be kept in mind that the disease occurs with moderate-severe pneumonia in this patient group. Disease progress can be stopped through early treatment.

Keywords: COVID-19, kidney transplantation, kidney recipients, kidney, immunosuppressive treatment

\section{Öz}

Amaç: COVID-19 tanılı böbrek nakli alıcılarında takrolimus (Tac), mikofenolat mofetil (MMF), mikofenolik asit (MPA), prednizolon (Pred) ve metilprednizolonun (MP) COVID-19 patogenezine ve progresyonuna etkisi olup olmadığını araştırmak.

Gereçler ve Yöntemler: Merkezimizin online veri tabanında geriye dönük olarak tarama yapıldı ve COVID-19 nedeniyle hastaneye yatırılan hastalardan böbrek nakilli hastalar tespit edildi. Şikayetleri, laboratuvar ve radyolojik veriler, uygulanan tedavi protokolleri ve hastaların son durumları ortaya koyuldu.

Bulgular: Toplam 11 hastanın \%73'ü (8) erkek, \%27'si (3) kadındı. Yaş ortalaması 49.63 (27-71) idi. Hipertansiyon ve diabetes mellitus en sık eşlik eden hastalıklardı. En sık görülen semptomlar öksürük, ateş ve halsizlik-yorgunluktu. Hemen hemen tüm hastalarda yüksek serum reaktif protein ve lenfopeni saptandı. Yedi hastada (\%73) akut böbrek yetmezliği oluşumu gözlendi. Tüm hastalar Tac ve Pred kullanırken, dokuz hasta (\%82) MMF ve iki hasta (\%18) MPA kullanıyordu. Hidroksiklorokin, favipiravir ve azitromisin, COVID-19 için uygulanan tedavilerdi. 11 hastanın RT-PCR sonucu 7'sinde pozitif, 4'ünde negatif bulundu. Taburcu edilen hastaların ortalama hastanede kalış süresi 8,8 gün olarak tespit edildi. Sekiz hasta iyileşerek taburcu edildi, entübe edilen iki hastanın tedavisi yoğun bakımda devam ederken bir hasta hayatını kaybetti.

Sonuç: Böbrek nakli yapılan hastalarda COVID-19'un klinik özellikleri genel popülasyonla benzerlik göstermektedir ve bu hasta grubunda hastalığın orta-şiddetli pnömoni ile ortaya çıktığı akılda tutulmalıdır. Erken aktif tedavi ile hastalığın ilerlemesi durdurulabilir.

Anahtar kelimeler: COVID-19, böbrek nakli, böbrek alıcısı, böbrek, immünsupresif tedavi

ORCID ID: $\begin{array}{ll}\text { S. Karadag } \\ \text { E. Sam }\end{array} \quad \begin{aligned} & 0000-0002-1420-4536 \\ & 0000-0001-7706-465 X\end{aligned}$

E. Sam $\begin{array}{ll}\text { M. Eksi } & 0000-0003-1490-3756 \\ \text { Y. Colakoglu } & 0000-0001-6432-765 X\end{array}$
K. Kart Yasar

0000-0003-2963-4894 


\section{Introduction}

A novel type of coronavirus disease emerged in December 2019 in Wuhan, the largest (and capital) city of Hubei Province in China [1]. Its rapid spread across the world led to it being declared a pandemic by the World Health Organization (WHO) [2]. The disease was named COVID-19 and the effective virus was named SARS-CoV-2 [3]. Although the disease generally affects the respiratory system, it also presents with different symptoms ranging from a mild cold to severe respiratory syndrome and can also affect kidneys, heart, skin, respiratory, and nervous systems [4,5]. Advanced age and presence of hypertension (HT), smoking, chronic obstructive pulmonary disease (COPD), and diabetes mellitus (DM) increase the risk and the extent of the effect of the disease [6-8]. Since immunosuppression is the most significant characteristic of COVID-19, patients with a suppressed immune system or those using immune system suppressing drugs constitute a particular population whose needs should be considered separately.

Kidney transplant patients would usually take immunosuppressive treatment, such as tacrolimus (Tac, calcineurin inhibitors), mycophenolate mofetil (MMF), mycophenolic acid (MPA), and steroids (Pred) or methylprednisolone (MP) [9]. There is no suitable, efficient, and clear treatment protocol is currently available for how these treatments should be applied for a patient with COVID-19 disease now.

Our aim in this study is to examine whether the continuous use of immunosuppressive drugs in kidney transplant patients is effective in the pathogenesis of COVID-19 and its effects on the progression of the disease. In addition, it is to examine the diagnosis, treatment and follow-up protocols applied in our center in the light of current COVID-19 literature and to determine a treatment specific to both COVID-19 and immunosuppression.

\section{Materials and Methods}

In this study, patients who were hospitalized and treated for COVID-19 in our center since 11 March 2020 (when the first COVID-19 patient was detected in our country) were evaluated retrospectively through the hospital's online database. Consent for the study was obtained from the Ethics Committee of University of Health Sciences, Dr. Sadi Konuk Training and Research Hospital (Ethics committee approval no: 2020/183).

Patients were identified who had been treated for COVID-19 and had also received a kidney transplant. Key parameters for these patients were examined as follows: demographic characteristics; complaints and symptoms at the time of first admittance; vital findings; thorax computed tomography (Tx-CT) findings; lowesthighest values for white blood cells (WBC), thrombocyte (Plt), lymphocyte (Lym), fibrinogen (Fib) creatinine (Cr), C-reactive protein (CRP), procalcitonin (Proc), D-dimer (DD), and ferritin (Fer); real-time polymerase chain reaction (RT-PCR) results; and drugs used before, for induction during, and after transplantation (anti-thymocyte globulin, ATG) plasmapheresis, rituximab, calcineurin inhibitor (Tac), antimetabolite (MMF/MPA), steroids (Pred/MP). In addition, further details were noted as follows: regulation of drugs during COVID-19 treatment (changing, discontinuing, and continuing dose adjustment); treatments specific for COVID-19 (hydroxychloroquine, HQ), azithromycin, oseltamivir, interleukin-6 blocker/tocilizumab, Favipiravir (Fav) and intravenous immunoglobulin (IVIG); antibacterial treatments; anticoagulant-antiaggregant treatments; vitamin-C use; intensive care unit (ICU) and intubation requirements; total hospitalization duration; and final condition (discharged, deceased, or continuing treatment).

Patients included in the study were those with kidney transplantation, with or without RT-PCR positive, and considered COVID-19 clinically and/or radiologically. Patients who were not considered COVID-19 clinically and radiologically during the follow-up and had a negative RT-PCR result were excluded from the study.

\section{Results}

Based on the examination, 11 patients met the inclusion criteria. Of these, $73 \%(n=8)$ of these patients were male and $27 \%(n=3)$ were female. The mean age was 49,63 (27-71) years. Live donor transplantation had been performed with six patients, deceased donor transplantation had been performed with four patients, and donor-type data could not be acquired for one patient (Table 1). Considering the mean time between kidney transplantation and infection was 24,4 (3-52) months. Comorbid diseases were HT for eight (73\%) patients, DM for three (27\%) patients, congestive heart failure (CHF) and COPD for one (9\%) patient, and three $(27 \%)$ patients had no comorbid diseases.

Although coughing (45\%), fever (45\%), weakness-exhaustion (45\%) and dyspnea (36\%) were observed most commonly, headache, diarrhea, myalgia, chills, nausea, and vomiting were also present among causes for admittance. Bilateral ground-glass appearance was observed in 9 patients $(81 \%)$, pleural effusion in three patients, and one-sided involvement in one patient (using Tx-CT). No significant pulmonary involvement was detected in just one patient.

Fever above $38^{\circ} \mathrm{C}$ was detected in two patients. While oxygen saturation was nearly $60 \%$ at room air in only one patient, it was over $93 \%$ for other patients and the mean value was $96.3 \%$. Apart from one patient, recorded blood pressures of all patients were within the normal range. The mean values for lowest-highest values were as follows: for complete WBC count 4.5-9.95 (10e3/uL); for Plt 144000-228000 (10e3/Ul); for Lym 0.5-1.14 (10e3/Ul) and for Fib 393-498 (mg/dL) respectively. Acute kidney injury (AKI) was observed in eight (73\%) of the patients with a mean basal $\mathrm{Cr}$ of $1.52 \mathrm{mg} / \mathrm{dL}$ (1.8-1.0) (Figure 1). Mean values for lowest and highest were detected for CRP 29-70 mg/L, Proc 0.19-5.9 ng/mL, Fer 468-673 $\mu \mathrm{g} / \mathrm{L}$ and DD 0.56-1.06 $\mu \mathrm{g} \mathrm{FEU} / \mathrm{mL}$ respectively.

It was observed that ATG was used for seven patients and pulse steroid was used for two patients for induction, whilst no 
Table 1. Patients demographics and outcomes

\begin{tabular}{c|c|c|c|c|c|c|c|c|c}
\hline Pt & Sex & Age & $\begin{array}{c}\text { Donor } \\
\text { type }\end{array}$ & $\begin{array}{c}\text { Time from } \\
\text { transplant to } \\
\text { infection } \text { (months) }\end{array}$ & ICU & INT & RT-PCR & $\begin{array}{c}\text { Hospital stay } \\
\text { (days) }\end{array}$ & Outcome \\
\hline 1 & M & 62 & LDRT & 44 & Yes & Yes & Positive & 11 & Death \\
\hline 2 & M & 44 & LDRT & 13 & No & No & Positive & 6 & Recovered \\
\hline 3 & F & 46 & DDRT & 19 & No & No & Positive & 11 & Recovered \\
\hline 4 & M & 71 & DDRT & 34 & Yes & Yes & Positive & Continues & - \\
\hline 5 & M & 60 & DDRT & 3 & No & No & Negative & 9 & Recovered \\
\hline 6 & F & 36 & LDRT & 9 & No & No & Negative & 13 & Recovered \\
\hline 7 & M & 37 & Unknown & 52 & No & No & Positive & 8 & Recovered \\
\hline 8 & M & 57 & LDRT & 45 & No & No & Positive & 7 & Recovered \\
\hline 9 & M & 50 & DDRT & 12 & No & No & Positive & 8 & Recovered \\
\hline 10 & M & 27 & LDRT & 18 & No & No & Negative & 7 & Recovered \\
\hline 11 & F & 56 & LDRT & 20 & Yes & Yes & Negative & Continues & - \\
\hline
\end{tabular}

DDRT: deceades donor received transplantation; F: female; ICU: intensive care unit; INT: intubation; LDRT: living donor received transplantation; M: male; Pt: patient; RT-PCR: real-time polymerase chain reaction

Figure 1. Levels of creatinine $(\mathrm{mg} / \mathrm{dL})$

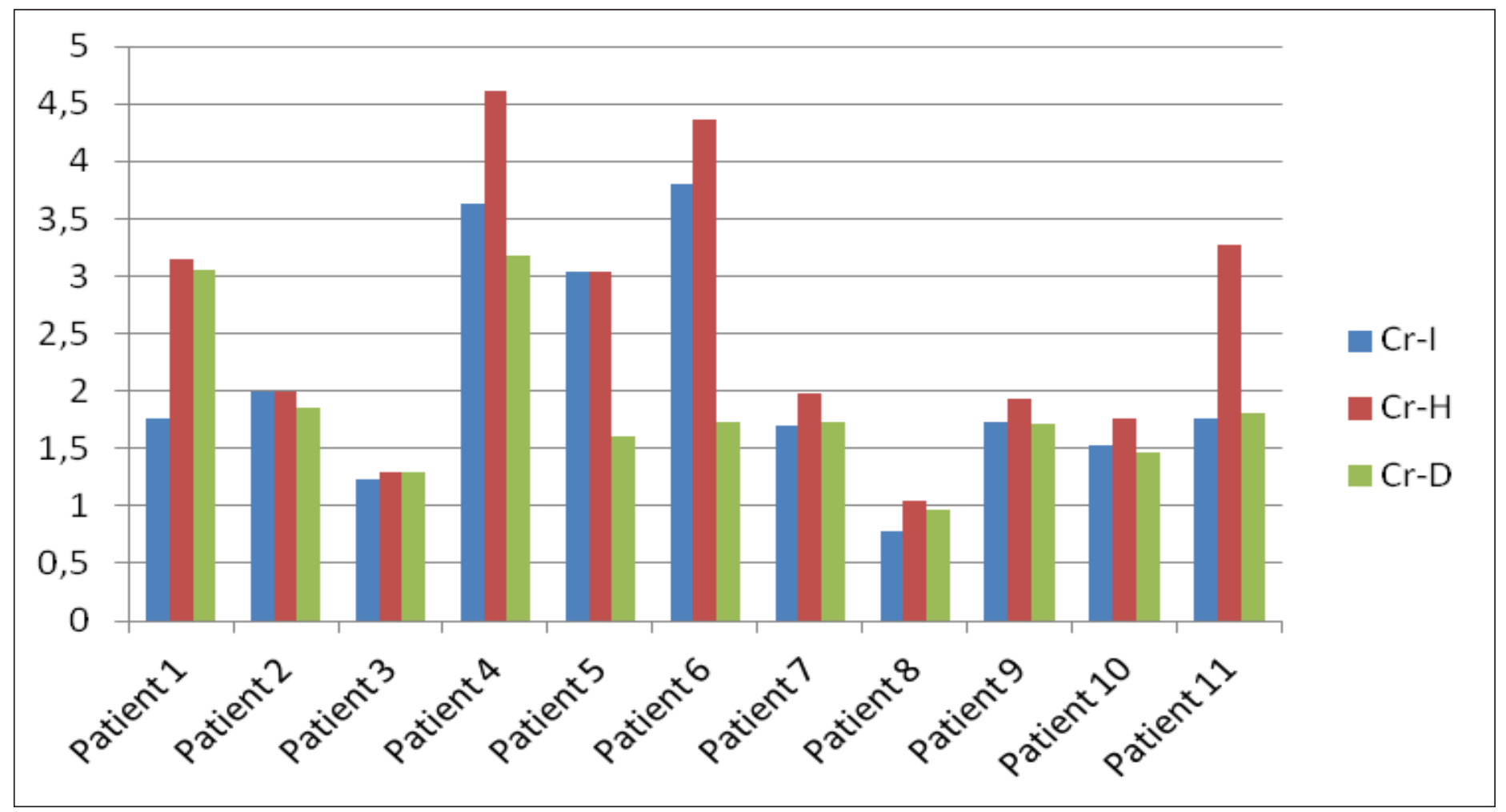

Cr-I: initial creatinine; Cr-H: highest creatinine; Cr-D: discharge creatinine

induction treatment was given for one patient due to a low risk in terms of immunity. For the purpose of desensitisation before transplantation, rituximab and plasmapheresis were applied. While all patients used Tac and Pred after transplantation, 9 patients (82\%) used MMF and two patients (18\%) used MPA as an antimetabolite. Antimetabolite treatment was discontinued for
10 patients, Tac was continued by either adjusting or decreasing dosages for 7 patients, and MP $(20 \mathrm{mg} /$ day dosage $)$ was given to all patients (Table 2).

As suggested by the World Health Organization (WHO), all patients received hydroxychloroquine (HQ) for 5-10 days (first day $2 \times 400 \mathrm{mg}$ loading, then $2 \times 100 \mathrm{mg}$ maintenance) 
Table 2. Transplant characteristics and outcomes

\begin{tabular}{c|c|c|c|c|c|c|c|c|c|c|c}
\hline Pt & Donor & Releated & $\begin{array}{c}\text { Degre of } \\
\text { relationship }\end{array}$ & Induction & Plasmapheresis & Rituximab & CNI & CNI-IL & Antimetabolite & Steroids & IR \\
\hline $\mathbf{1}$ & LDRT & Yes & Wife & ATG & No & No & Tac & 2,47 & MMF & Pred & Only MP \\
\hline $\mathbf{2}$ & LDRT & Yes & Mother & P.Steroid & No & No & Tac & 5,34 & MMF & Pred & No Change \\
\hline $\mathbf{3}$ & DDRT & - & - & ATG & No & No & Tac & 9,58 & MPA & Pred & Only MP \\
\hline $\mathbf{4}$ & DDRT & - & - & ATG & Yes & No & Tac & 17 & MMF & Pred & Only MP \\
\hline $\mathbf{5}$ & DDRT & - & - & ATG & No & No & Tac & 15,4 & MMF & Pred & Tac + MP \\
\hline $\mathbf{6}$ & LDRT & Yes & Mother & ATG & Yes & Yes & Tac & 11,4 & MMF & Pred & Tac+ MP \\
\hline $\mathbf{7}$ & Unknown & - & - & Unknown & Unknown & Unknown & Tac & 8,03 & MMF & Pred & Tac+ MP \\
\hline $\mathbf{8}$ & LDRT & Yes & Wife & No & No & No & Tac & 13,13 & MMF & Pred & Tac+ MP \\
\hline $\mathbf{9}$ & DDRT & - & - & ATG & Yes & Yes & Tac & 19,05 & MMF & Pred & Tac+ MP \\
\hline $\mathbf{1 0}$ & LDRT & Yes & Brother & P.Steroid & No & No & Tac & 5,16 & MMF & Pred & Tac+ MP \\
\hline $\mathbf{1 1}$ & LDRT & Yes & Sister & ATG & Yes & Yes & Tac & 2,59 & MPA & Pred & Tac+ MP \\
\hline
\end{tabular}

ATG: antithymocyte globulin; CNI: calcineurin inhibitor; DDRT: deceades donor received transplantation; IL: initial level; IR: immune regulation; LDRT: living donor received transplantation; MMF: mycophenolate mofetil; MP: methylprednisolone; MPA: mycophenolic acid; P: pulse; Pt: patient; Pred: prednisolone; Tac: Tacrolimus

Table 3. COVID-19 specific treatment

\begin{tabular}{c|c|c|c|c|c|c|c|c|c}
\hline $\mathbf{P t}$ & HQ & Os & Az & Tos & Fav & IVIG & Antimicrobial treatments & Thromboprophylaxis & Asc. A \\
\hline $\mathbf{1}$ & Yes & Yes & Yes & No & Yes & No & Piperacillin-Tazobactam & LMWH & No \\
\hline $\mathbf{2}$ & Yes & Yes & No & No & No & No & No & No & No \\
\hline $\mathbf{3}$ & Yes & Yes & Yes & No & No & No & No & LMWH & No \\
\hline $\mathbf{4}$ & Yes & Yes & Yes & No & Yes & No & Ceftapenem & Yes \\
\hline $\mathbf{5}$ & Yes & No & No & No & No & No & Ceftriaxone & LMWH & No \\
\hline $\mathbf{6}$ & Yes & No & No & No & No & No & No & LMWH & No \\
\hline $\mathbf{7}$ & Yes & No & Yes & No & No & No & No & ASA & No \\
\hline $\mathbf{8}$ & Yes & No & No & No & No & No & No & LMWH & No \\
\hline $\mathbf{9}$ & Yes & No & Yes & No & No & No & Ceftriaxone & LMWH & No \\
\hline $\mathbf{1 0}$ & Yes & No & No & No & No & No & LMWH+ASA & Yes \\
\hline $\mathbf{1 1}$ & Yes & No & No & No & Yes & No & Ertapenem+Vancomycin+Meropenem & NMH & No \\
\hline
\end{tabular}

ASA: acetylsalicylic acid; Asc. A: ascorbic acid; Az: azithromycin; Fav: favipiravir; HQ: hydroxychloroquine; IVIG: intravenous immunoglobulin; LMWH: low molecular weight heparin; Os: oseltamivir; Pt: patient

and six patients received azithromycin for 5 days $(1 \times 500$ $\mathrm{mg}$ on first day, then $1 \times 250 \mathrm{mg}$ ) in line with COVID-19 Treatment Guidelines prepared by the Science Board formed within the Ministry of Health in our country [10]. In addition to the treatments mentioned here, 4 patients were also given oseltamivir $(2 \times 75 \mathrm{mg} /$ day for 5 days $)$ in the early period of the pandemic. All patients were given an electrocardiogram before starting these treatments and QT distances were calculated and detected within normal ranges for all patients. According to our Ministry of Health's COVID-19 guidelines, 3 patients received a 5 -day treatment regimen of Fav $(2 \times 1600 \mathrm{mg} /$ day loading, $2 \times 600$ $\mathrm{mg}$ /day maintenance). Neither tocilizumab not IVIG treatment were used for any of the patients. Ceftriaxone, ertapenem, vancomycin, and piperacillin-tazobactam were used for six patients requiring antimicrobial treatment. Low molecular weight heparin (LMWH) enoxaparin sodium $(4000 \mathrm{IU} / 0.4 \mathrm{ml}$ or $6000 \mathrm{IU} / 0.6 \mathrm{ml}$ ) and $100 \mathrm{mg} /$ day acetylsalicylic acid alone or in combination were used for thromboprophylaxis (Table 3).

While COVID-19 was confirmed through RT-PCR in 7 of 11 patients $(63.6 \%)$ from laboratory diagnosis, 4 patients were RT-PCR negative (Table 1). COVID-19 was diagnosed through clinical, laboratory, and pulmonary tomography findings in our RTPCR negative cases. Eight patients recovered and were discharged (72.7\%); two intubated patients remain under treatment in the 
ICU (18.2\%) (during the writing process of this manuscript), and one patient died $(9.1 \%)$. The mean hospitalization duration for discharged patients was 8.8 days (Table 1).

\section{Discussion}

In terms of gender, parallel to general population data reporting that COVID-19 is more commonly presented in males, $73 \%$ of our patients were male [11]. Interestingly, the mean age was lower (49,63 years) compared to the general population. Considering our youngest patient was 27 years old, it should be recognised that all age groups are at risk of this disease. Since the deceased-live donor rate in our country is approximately $30 \%-70 \%$, a similarity was observed in kidney transplanted COVID-19 patients in terms of the deceased-live donor rate.

Published studies have shown that comorbid diseases play a significant part in the overall effects of COVID-19 [12]. Similar to the literature, our study shows that HT, DM, COPD and CHF are among the leading causes of increased risk. It should be recognised that a comorbid disease increases the risk; however, it is equally important to keep in mind that COVID-19 can also affect otherwise healthy individuals. Because our study showed that our two patients had no comorbidity.

Considering the reports in terms of the time passing between transplantation and infection formation, patient groups within a time range expressed as day, month, or year are also present [11]. Intensive use of immunosuppression can worsen the course of the disease. On the other hand, reducing the dose may cause deterioration of the graft function and thus the emergence of AKI and worsening of the situation [13].

The WHO have separated COVID-19-related symptoms into three groups: common, less common, and severe. While fever, dry cough, and fatigue are common, symptoms such as pain and aches, sore throat, diarrhea, conjunctivitis, headache, inability to taste or smell, skin rash, or colour change in fingers or toes were stated as fewer common symptoms. Severe symptoms include breathing difficulty or dyspnea, chest pain or tightness, and loss of speaking or movement [14]. Although these symptoms are applied to the general population, the symptoms among our patient group were parallel to the general population.

While mild-to-moderate symptoms we mostly detected among the general population in radiological terms, moderate-to-severe pulmonary symptoms were detected at a rate of $90 \%$ among our patient group. Only one patient had no remarkable pulmonary effects. Accordingly, we consider pulmonary involvement to be more common among patients with kidney transplantation, and it would therefore be accurate to predict that pneumonia might have a more severe course.

Lymphopenia was reported as the most characteristic aspect of COVID-19 in terms of laboratory variables. Authors emphasise that, together with lymphopenia, CRP, Fer, and DD increases, Proc may also increase in the case of bacterial co-infection [15]. It was also reported that Plt and Fib increased in mild-to-moderate cases based on the disease condition, but may decrease in severe cases.
Among our sample, high CRP and Fer were observed together with lymphopenia in all patients (100\%), Fib increase was observed in $82 \%$, and DD increase was observed in $54 \%$ of patients. Three patients had high procalcitonin and the fact that one of these patients died and the other two were intubated in ICU (during the writing process of this manuscript) shows that high Proc likely increases mortality risk and can be a predictive factor. As in the general population, we recommend the use of lymphopenia and high CRP, Fer, Fib, and DD for COVID-19 diagnosis among patients who have had kidney transplantation.

Many different approaches were identified among the immunosuppressive treatments presented in this study. The application of many different protocols were reported, such as the continuation of present treatments, completely ceasing treatment, increase treatment dosage, only cutting antimetabolites, continuing only with Pred or MP, or use of Tac and MP [16-18]. With so many different options being used, the novel character of COVID-19 and a lack of adequate information infrastructure is resulting in a lack of an efficient, reliable, and suitable treatment protocol. Treatments may differ as different types and doses of immunosuppressives used for each patient is a factor affecting each patient clinic. We think that treatment should be evaluated based on each patient and regulated depending on the mildmoderate-severe character of the disease. In the case of mild disease, the dose of Tac should be adjusted (drug interactions with lopinavir/ritonavir, HQ etc.), closely followed-up, and decreased if necessary, whilst antimetabolites can be used very carefully to preserve graft function in the patient group without any severe change in laboratory parameters. However, since most patients have lymphopenia, the correct approach would be to commence antimetabolites after the laboratory parameters return to normal. Only low dose Tac should be given in moderate cases of the disease, and Tac should be discontinued in severe disease presentations, such as in ICU and intubation. Furthermore, we suggest that MP should be administered at $20 \mathrm{mg} /$ day MP in all disease groups.

Although there is no specific and efficient treatment for COVID-19 as yet, HQ, lopinavir+ritonavir, remdesivir, Fav, convalescent plasma, and Interleukin-6 (IL-6) blockers are the drugs currently being used [19]. On the other hand, promising vaccination studies on COVID-19 continue rapidly all over the world. Most of the mRNA vaccines which are a new technological product and inactive coronavirus vaccines, announced the phase 3 results, and many countries in the world, including our country, are gradually carrying out vaccination studies. Azithromycin and oseltamivir have also been used in the early periods of the pandemic, they are not suggested as treatment since the studies demonstrated that they have no efficiency. The drugs most commonly used are HQ and lopinavir+ritonavir, which are suggested for all mild-moderate and severe patient groups [2022]. Conversely, remdesivir, convalescent plasma and Fav are used in the advanced stage of the disease [23-25]. It was reported that IL-6 blocker-tocilizumab was given in cases of cytokine storm and IVIG was given in cases of severe disease [26,27]. It is 
recommended that the ECG should be checked at intervals before commencing the treatment and at intervals during the treatment, as HQ and azithromycin may lengthen the QT range and cause lethal arrhythmias. No negative condition was detected in terms of arrhythmia among our patient group.

Among antiviral drugs, Fav is more commonly used in our country [10]. Again, while Fav was used in cases of severe disease in the early periods of the pandemic, we observed that Fav would be more effective when started in patients with lowered oxygen saturation in the early periods of the disease and would reduce the need for ICU and intubation. When we examined why the treatment was not effective for three patients given Fav treatment, it was evident that for these patients at the time of admission to the hospital, one was intubated (deceased patient) and the other two patients were at an advanced stage (intubated at follow-up) of the disease. This result has shown that the initiation of Fav therapy in the early stages of the disease supports our view, as already emphasised. We will be able to reach objective conclusions from the data when the clinical study in our center is completed.

Considering that bacterial co-infection may be present when the disease has a slow course and clinical and laboratory recovery is not observed, a wide spectrum antibiotic should be added to the treatment regime. In our patients with resistant high fever and persistent or increasing highly acute phase, ceftriaxone, piperacillin-tazobactam, ertapenem, meropenem, and vancomycin were added as antibacterial treatment.

Many clinical and postmortem studies have reported that COVID-19 creates a tendency toward thrombosis and the thrombotic incidence accordingly causes systemic symptoms $[5,28,29]$. Thus, it is suggested that prophylaxis is given or treatment to prevent a thromboembolic event is provided to patients [30]. Except one patient all of them were given 4000IU/LMWH prophylaxis. Patients for whom thrombosis-related symptoms (tachypnea) or examination findings were detected the dose was adjusted according to the weight and LMWH was switched to the treatment dose $(\times 2)$.

Our study has some limitations. Including a small number of patients, retrospective and observational study nature, and a lack of information on outpatients were all factors considered among these limitations.

\section{Conclusion}

From our study, it should be considered that although the clinical characteristics of COVID-19 among kidney transplant patients are similar to the general population, the disease occurs with moderate-severe pneumonia among this patient group. Furthermore, it should be considered that commencing active treatment early would positively affect the progression of the disease which would also be overcome with less harm to patients. Although prospective and randomised controlled studies with a higher number of patients are needed, we think that our study can contribute to related literature.
Ethics Committee Approval: The study was approved by University of Health Sciences, Dr. Sadi Konuk Training and Research Hospital Ethical Committee, Bakirkoy, Istanbul, Turkey (Approval number, and registration number: 04.05.2020/183).

Informed Consent: An informed consent was obtained from all the patients for research.

Publication: The results of the study were not published in full or in part in form of abstracts.

Peer-review: Externally peer-reviewed.

Authorship Contributions: Any contribution was not made by any individual not listed as an author. Concept-K.K,Y., S.K., R.U.; Design - R.U., E.S.; Supervision - K.K.Y., S.K., R.U.; Resources - R.U., E.S.; Materials - R.U., E.S., Y.C.; Data Collection and/or Processing - R.U., E.S.; Analysis and/or Interpretation - K.K.Y., S.K., R.U.; Literature Search - R.U., E.S.; Writing- R.U., K.K.Y., M.E.; Critical Review - K.K.Y., S.K., R.U., M.E.

Conflict of Interest: The authors declare that they have no conflict of interest.

Financial Disclosure: The authors declare that this study received no financial support.

\section{References}

[1] Novel coronavirus (2019-nCoV): Situation report - 1, 20 January 2020. World Health Organization, 2020.

[2] Coronavirus disease 2019 (COVID-19) Situation Report 23, 11 March 2020. World Health Organization, 2020.

[3] Novel coronavirus (2019-nCoV): Situation report - 22, February 2020. Geneva: World Health Organization, 2020.

[4] Galván Casas C, Català A, Carretero Hernández G, RodríguezJiménez P, Fernández Nieto D, Rodríguez-Villa Lario A, et al. Classification of the cutaneous manifestations of COVID-19: a rapid prospective nationwide consensus study in Spain with 375 cases. Br J Dermatol 2020;183:71-7. https://doi.org/10.1111/bjd.19163.

[5] Pranata R, Huang I, Lim MA, Wahjoepramono PEJ, July J. Impact of Cerebrovascular and Cardiovascular Diseases on Mortality and Severity of COVID-19 - Systematic Review, Meta-analysis, and Meta-regression. J Stroke Cerebrovasc Dis 2020;29:104949.

https://doi.org/10.1016/j.jstrokecerebrovasdis.2020.104949.

[6] Zheng Z, Peng F, Xu B, Zhao J, Liu H, Peng J, et al. Risk factors of critical \& mortal COVID-19 cases: A systematic literature review and meta-analysis. J Infect 2020;81:e16-e25. https://doi.org/10.1016/j.jinf.2020.04.021.

[7] Yang J, Zheng Y, Gou X, Pu K, Chen Z, Guo Q, et al. Prevalence of comorbidities and its effects in patients infected with SARS-CoV-2: a systematic review and meta-analysis. Int J Infect Dis 2020;94:91-5. https://doi.org/10.1016/j.ijid.2020.03.017.

[8] Huang C, Wang Y, Li X, Ren L, Zhao J, Hu Y, et al. Clinical features of patients infected with 2019 novel coronavirus 
in Wuhan, China. Lancet 2020;395:497-506.

https://doi.org/10.1016/S0140-6736(20)30183-5.

[9] Rodríguez Faba O, Boissier R, Budde K, Figueiredo A, Taylor CF, Hevia V, et al. European Association of Urology Guidelines on Renal Transplantation: Update 2018. Eur Urol Focus 2018;4:208-15. https://doi.org/10.1016/j.euf.2018.07.014.

[10] Republic of Turkey Ministry of Health-19 COVID-19 (SARS-cov2 Infection) guide, 11 March 2020.

[11] Johnson KM, Belfer JJ, Peterson GR, Boelkins MR, Dumkow LE. Managing COVID-19 in Renal Transplant Recipients: A Review of Recent Literature and Case Supporting Corticosteroid-sparing Immunosuppression. Pharmacotherapy 2020;40:517-24. https://doi.org/10.1002/phar.2410.

[12] Zhu L, Gong N, Liu B, Lu X, Chen D, Chen S, et al. Coronavirus Disease 2019 Pneumonia in Immunosuppressed Renal Transplant Recipients: A Summary of 10 Confirmed Cases in Wuhan, China. Eur Urol 2020;77:748-54. https://doi.org/10.1016/j.eururo.2020.03.039.

[13] Fanelli V, Fiorentino M, Cantaluppi V, Gesualdo L, Stallone G, Ronco C, et al. Acute kidney injury in SARSCoV-2 infected patients. Crit Care 2020;24:155. https://doi.org/10.1186/s13054-020-02872-z.

[14] Coronavirus Symptoms.World Health Organization. https://www.who.int/westernpacific/health-topics/ coronavirus (accessed June 6, 2020).

[15] Akalin E, Azzi Y, Bartash R, Seethamraju H, Parides M, Hemmige V, et al. Covid-19 and Kidney Transplantation. N Engl J Med 2020;382:2475-7. https://doi.org/10.1056/NEJMc2011117.

[16] Kronbichler A, Gauckler P, Windpessl M, Il Shin J, Jha V, Rovin BH, et al. COVID-19: implications for immunosuppression in kidney disease and transplantation. Nat Rev Nephrol 2020;16:365-7. https://doi.org/10.1038/s41581-020-0305-6.

[17] Zhu L, Xu X, Ma K, Yang J, Guan H, Chen S, et al. Successful recovery of COVID-19 pneumonia in a renal transplant recipient with long-term immunosuppression. Am J Transplant 2020;20:1859-63. https://doi.org/10.1111/ajt.15869.

[18] Zhong Z, Zhang Q, Xia H, Wang A, Liang W, Zhou W, et al. Clinical characteristics and immunosuppressant management of coronavirus disease 2019 in solid organ transplant recipients. Am J Transplant 2020;20:1916-21. https://doi.org/10.1111/ajt.15928.

[19] Şimşek Yavuz S, Ünal S. Antiviral treatment of COVID-19. Turk J Med Sci 2020;50:611-9. https://doi.org/10.3906/sag-2004-145.

[20] Abrishami A, Samavat S, Behnam B, Arab-Ahmadi M, Nafar M, Sanei Taheri M. Clinical Course, Imaging
Features, and Outcomes of COVID-19 in Kidney Transplant Recipients. Eur Urol 2020;78:281-6. https://doi.org/10.1016/j.eururo.2020.04.064.

[21] Gautret P, Lagier J-C, Parola P, Hoang VT, Meddeb L, Mailhe $\mathrm{M}$, et al. Hydroxychloroquine and azithromycin as a treatment of COVID-19: results of an open-label non-randomized clinical trial. Int J Antimicrob Agents 2020;56:105949. https://doi.org/10.1016/j.ijantimicag.2020.105949.

[22] Nair V, Jandovitz N, Hirsch JS, Nair G, Abate M, Bhaskaran $\mathrm{M}$, et al. COVID-19 in kidney transplant recipients. Am J Transplant 2020;20:1819-25. https://doi:10.1111/ajt.15967.

[23] Grein J, Ohmagari N, Shin D, Diaz G, Asperges E, Castagna A, et al. Compassionate Use of Remdesivir for Patients with Severe Covid-19. N Engl J Med 2020;382:2327-36. https://doi.org/10.1056/NEJMoa2007016.

[24] Roback JD, Guarner J. Convalescent Plasma to Treat COVID-19: Possibilities and Challenges. JAMA 2020;323:1561-2. https://doi.org/10.1001/jama.2020.4940.

[25] Chen C, Zhang Y, Huang J, Yin P, Cheng Z, Wu J, et al. Favipiravir versus Arbidol for COVID-19: A Randomized Clinical Trial. MedRxiv 2020:2020.03.17.20037432. https://doi.org/10.1101/2020.03.17.20037432.

[26] Allam SR, Dao A, Madhrira MM, Antiporta PB, Nair RR, Guiteau JJ, et al. Interleukin-6 Receptor Antagonist Therapy to Treat SARS-CoV-2 Driven Inflammatory Syndrome in a Renal Transplant Recipient. Transpl Infect Dis 2020;22:e13326. https://doi.org/10.1111/tid.13326.

[27] Fontana F, Alfano G, Mori G, Amurri A, Tei L, Ballestri $\mathrm{M}$, et al. COVID-19 pneumonia in a kidney transplant recipient successfully treated with tocilizumab and hydroxychloroquine. Am J Transplant 2020;20:1902-6. https://doi.org/10.1111/ajt.15935.

[28] Wichmann D, Sperhake J-P, Lütgehetmann M, Steurer S, Edler C, Heinemann A, et al. Autopsy Findings and Venous Thromboembolism in Patients With COVID-19. Ann Intern Med 2020;173:268-77. https://doi.org/10.7326/M20-2003.

[29] Menter T, Haslbauer JD, Nienhold R, Savic S, Hopfer $\mathrm{H}$, Deigendesch N, et al. Post-mortem examination of COVID-19 patients reveals diffuse alveolar damage with severe capillary congestion and variegated findings of lungs and other organs suggesting vascular dysfunction. Histopathology 2020;77:198-209. https://doi.org/10.1111/his.14134.

[30] Tang N, Bai H, Chen X, Gong J, Li D, Sun Z. Anticoagulant treatment is associated with decreased mortality in severe coronavirus disease 2019 patients with coagulopathy. J Thromb Haemost 2020;18:1094-9. https://doi.org/10.1111/jth.14817. 